\title{
ARTICLE \\ Evaluating Rice Biodiversity and Yields of Upland Rice Landraces Grown in Shifting Cultivation in Bandarban, Bangladesh
}

\author{
Abdul Hamid $^{1 *}$ Jatish C. Biswas $^{2}$ M. Mahirul Islam Biswas ${ }^{1}$ Faruque H. Mollah ${ }^{1}$ Thwi $^{2}$ \\ Mong Marma ${ }^{1}$ Aung Swiy Sing Marma ${ }^{1}$ Mong Sanue Marma ${ }^{3}$ Kironmoy Dewan $^{3}$
}

1.Agrarian Research Foundation, Dhaka, 1207, Bangladesh

2.Krishi Gobeshona Foundation, BARC Complex, Farmgate, Dhaka 1215, Bangladesh

3.Hill Cotton Research Station, Cotton Development Board, Balaghata, Bandarban 4600, Bangladesh

\begin{tabular}{l}
\hline ARTICLE INFO \\
\hline Article history \\
Received: 31 March 202 \\
Accepted: 26 April 202 \\
Published Online: 15 \\
\hline Keywords: \\
Shifting cultivation \\
Upland rice \\
Landraces \\
Grain yield \\
Relative performance
\end{tabular}

\section{Introduction}

Shifting cultivation, swidden culture, or popularly known as jhum cultivation in South and Southeast Asian countries is waning. In the wake of economic and social transformation, government regulations came down heavily transforming shifting cultivation into market oriented settled agriculture ${ }^{[1,2]}$. In Bangladesh, however, shifting cultivation still remains a dominant

\begin{abstract}
Shifting cultivation, popularly known as jhum, is a dominant form of agriculture in the Chattogram Hill Tracts (CHT) of Bangladesh with upland rice being the major component of the system. The region is known for its rice biodiversity, which is under threat. This study was an attempt to explore the extent of rice biodiversity and variation in rice yields observing 81 randomly selected shifting cultivation plots from 26 dispersedly located mountainous villages in four sub-districts of Bandarban, one of three districts of the CHT. A total of 28 landraces of upland rice was grown in shifting cultivation. Highest number of landraces (16) was found in sub-district Thanchi. Three landraces most frequently observed were Gunda, Maemonsing and Sadabinni. Rice grain yield varied between $1.421 \mathrm{t}$ ha- 1 and $3.442 \mathrm{t}$ ha- 1 across landraces with the highest being recorded for Patobi. Landrace Dilon the lowest yield. Relative performance of landraces Kobrokbinni, Maemonsing, Monthon, Patobi and PD were superior to standard BRRI dhan 83 and Gunda in relation to grain yield. Some of these landraces having wider adaptability may be released as varieties.
\end{abstract}

form of crop production in the sloping highlands of mountainous CHT ${ }^{[3,4]}$. The region, located in the southeast corner of Bangladesh, comprises three hill districts - Bandarban, Khagrachari and Rangamati. Geographically a part of Hindu Kush-Himalaya, the CHT is home to 12 ethnic communities. Unlike in the floodplains constituting a major segment of the country, the rugged, undulating mountainous lands of the CHT cover about $10 \%$ of the country's total landmass. However, only

*Corresponding Author:

Abdul Hamid,

Agrarian Research Foundation, Dhaka 1207, Bangladesh;

Email:hamid50.arf@gmail.com 
$3.1 \%$ of the CHT land area is suitable for crop growing year-round while $74 \%$ represents hills and mountains with $2.72 \%$ sloping uplands ${ }^{5}$. High elevation hills and mountains are more and the proportion of arable land is less in Bandarban compared with other two hill districts of the CHT.

Two types of agricultural practices are prevalent in the CHT: plough agriculture or crop production in the valley lands using plowing as is being followed in plain lands, and traditional shifting cultivation in the sloping uplands in the hilly and mountainous areas. Shifting cultivation or jhum system is dominant and widely practiced for crop production in Bandarban ${ }^{[4,6]}$. In the shifting cultivation, farmers grow several crops together with rice being dominant under rainfed condition. Reliable statistics on area and production under jhum in the CHT are hard to get; but it is generally assumed that about 70,000 farmers practice jhum covering a minimum of 40,000 ha annually. The region is known for genetic diversity in rice [7].

Mountainous region comprising northern Myanmar, the CHT and northeasters Himalayan states of India might be center of diversity of Asian rice ${ }^{[8]}$. In uplands of the CHT farmers generally grow upland rice landraces in shifting cultivation that thrives depending on rainfall since irrigation cannot be provided in the sloping hilly lands. Many of the farmers prefer growing sticky and specialty rice cultivars. These upland rice landraces are traditionally grown in low-input, subsistence systems as is being practiced in similar environments in north-eastern India ${ }^{[9]}$ and south-east Asian countries ${ }^{[10-12]}$. Invariably no farmer cultivates high yielding rice varieties in the shifting cultivation system.

Upland rice yield in the mountainous areas of the CHT is generally low ${ }^{[13,14]}$ which may be attributed to culture type, land topography, rainfall characteristics and the varieties that farmers use ${ }^{[15]}$. Spatial differences in upland rice yields and varieties used have been reported ${ }^{[16]}$. Choudhury et al. ${ }^{[17]}$ studied genetic structure and diversity of indigenous rice varieties grown in the Eastern Himalayan region of Northeast India. Atlin et al. ${ }^{[18]}$ evaluated indica upland genotypes against traditional and improved tropical japonica upland varieties and elite indica high-yielding varieties (HYV) under high-fertility favorable upland conditions for characterizing the features of tested entries. Recently, Van Andel et al. ${ }^{[19]}$ studied the diversity of rice genotypes used by the Guianas farmers in their traditional farming systems. Food insecurity is a major concern in such situations. Our earlier study conducted in Bandarban ${ }^{[14]}$ also suggests that low yields of upland rice crop in shifting cultivation led to food insecurity of a greater segment of ethnic farmers. Mahmud et al. ${ }^{[20]}$ suggested that improved management practices in rice replacing indigenous landraces with drought tolerant varieties might improve yield.

Yields of crops including upland rice are directly influenced by biophysical characteristics (www. ohchr.org/Documents/Issues/EPoverty/Lao/MilesKenneyLazarAnnex 5.pdf) along with varietal differences ${ }^{[21]}$. Ran et al. ${ }^{[22]}$ also showed that of all the factors associated with rice yield variation in mountainous terrain of southwest China, variety had more influence. In contrast, Sadimantara et al. ${ }^{[23]}(2018)$ reported fairly stable yields of local varieties of upland rice in Sulawesi of Indonesia. Roy et al. ${ }^{[24]}$ evaluated 68 hill rice landraces of Northeast Indian states and categorized them in early and late maturing groups based on plant height, kernel length, kernel length-to-width ration, grain length, and grain length-to-width ratio. Similar information on genotypic variation in upland rice in Bangladesh is either scanty or unavailable, although Siddique et al. ${ }^{[25]}$ studied the varietal differences of upland rice under lowland conditions and reported large variation in grain morphology. Some other authors reported low yields of indigenous rice in shifting cultivation or jhum in the CHT ${ }^{[14,26]}$; but work on yield variability and diversity of jhum rice has not been reported. This study was an attempt to evaluate the extent of rice biodiversity and yield potentials of upland rice genotypes grown in shifting cultivation in the uplands of Bandarban district in Bangladesh.

\section{Materials and Methods}

This on-farm study was conducted sampling shifting cultivators' plots, enumerating the rice landraces grown in shifting crops, and determining grain yields harvesting rice from the selected plots. Farmers established their shifting cultivation plots slashing forest, burning and clearing debris, and dibbling seeds following rains (April - May, 2019) without resorting to tillage on the mountainous uplands ${ }^{[27]}$. Once the shifting cultivation plots were established in the rugged terrains of hills and mountains, a team of Agrarian Research Foundation (AR) travelled through four upazila (sub-districts) of Bandarban district in June-July, 2019 to select farmers and their plots. Invariably all farmers in the selected locations planted upland rice in shifting cultivation plots, albeit the rice varieties and associated crops varied across locations. Visiting cropped areas and discussing with farmers, shifting cultivation plots were selected at random from 26 dispersedly located para (villages) of four upazila (sub-districts). A total of 81 plots, each measuring 
one kani ( $0.16 \mathrm{ha})$ or more and the owner farmers thereof were selected for the study. Rice landraces planted in each plot were identified interviewing the owner farmers.

Rice crop attained maturity at different times beginning late-August through early October depending on planting time and landraces used by the farmers. Rice peduncle (panicle base) turning to yellow was taken as physiological maturity ${ }^{[28]}$. From each selected plot, three quadrants of rice, each quadrant measuring $1.0 \mathrm{~m} \times 5.0 \mathrm{~m}$, were sampled and harvested at maturity. Harvested rice of three quadrants of each plot was threshed and brought to ARF Office, Reicha (Bandarban) and sundried to a constant weight. Moisture content of dried rice samples was recorded, adjudged to $12 \%$ moisture content and converted to grain yield per ha. In view of unequal sample size in respect of number of farmers planted to each variety, variation in agronomic practices for growing rice across locations, and heterogeneity of experimental plots, analysis of variance could not be performed. However, rice grain yield data of each variety and location were subjected to descriptive statistical analysis wherever feasible.

Yield performance of landraces grown in shifting cultivation was compared with modern variety BRRI dhan 83 and cultivar Gunda using Relative Performance (RP) as follows:

\section{$\mathrm{RP}=($ Grain yield of landraces $) /$ grain yield of BRRI dhan 83 or Gunda}

Average yield data of BRRI dhan 83 were taken from a trial recently conducted in nine upazila of the $\mathrm{CHT}^{[29]}$ while the average grain yield of Gunda was taken from the present study. The performance of a genotype was considered satisfactory when RP was $\geq 1$.

\section{Results and Discussion}

Selected farmers in 26 different locations (para) of four upazila in Bandarban district had planted 28 landraces of upland rice (Table 1). The cultivar most frequently observed was Gunda planted in eight locations followed by landraces Maemonsing and Sadabinni. The landrace Gunda was mostly concentrated in a few villages (para) in Rowangchari and Bandarban sadar upazila, while Sadabinni was dispersedly planted across four upazila of Bandarban district. Landrace Maemonsing was grown in mountains covering a cluster of three villages of three adjoining upazila- Rowangchari, Bandarban sadar and Ruma. Likewise, the production of cultivar Monthon was concentrated in high hills of Ruma and Thanchi upazila. Although few farmers planted landraces Batia, Chama, Chilikma, Dilon, Kanbui, Monbui, and Rongkui (Table 1), because of low yield potentials and growing food demand these landraces are progressively being extinct. Tribal people in the CHT prefer glutinous aromatic and specialty rice like Binni, Patobi, Rigui, Chilikma, a few farmers planted such genotypes because of their low yields.

Table 1 indicates that Thanchi upazila was the area for wider diversity of upland rice genotypes which was followed by Rowangchari. As many as 28 different landraces of upland rice were grown in association with other crops in jhum culture. Apart from commonly grown upland rice landraces, Thanchi farmers planted 12 more landraces compared with other three upazilas. In contrast, lesser numbers but more frequently observed landraces were grown in Bandarban sadar upazila. Sampled farmers in Thanchi upazila planted eight indigenous rice landraces which were mutually exclusive of the cultivars grown in other upazilas. Our findings indicate that Bandarban, located in the Indo-Burma border, still remains a biodiversity hotspot of a large number of indigenous rice landraces in the region. Valalsanga et al. ${ }^{[30]}$ also recently indicated high genetic diversity of rice genetic resources in neighboring states of northeast India.

The number of farmers' plots we sampled in Ruma upazila was less compared with other three upazilas. The reason of fewer samplings in Ruma upazila was primarily due to distance from the district town (Bandarban) and jhum plots being located in relatively inaccessible areas. Such unequal sample size thus presented problem in running statistical analysis.

In the present study, a total of 81 plots of shifting cultivators were evaluated (Table 2). Eight farmers of five villages planted a fairly recently introduced cultivar Gunda in mid-range hills in Bandarban sadar and Rowanghchari upazila. The second most frequently used cultivars were Maemonsing and Sadabinni. Maemonsing was planted in high-range mountainous areas in three villages of Bandarban sadar, Rowangchari and Ruma upazila. Regardless of ranges of hills and mountains, Sadabinni genotype was widely grown throughout the four upazila in Bandarban district. Monthon genotype was also concentrated in the high range hills and mountains of Rowangchari and Thanchi upazila. Each of the two aromatic, glutinous rice varieties Kalobinni and Lal binni were planted by five farmers. Kalobinni was grown in high-range hills in southern part of Bandarban sadar while Lal binni occurred in low hills in Bandarban sadar, Rowangchari and Ruma upazila. 
Table 1. Spatial distribution of rice varieties in four upazila of Bandarban district

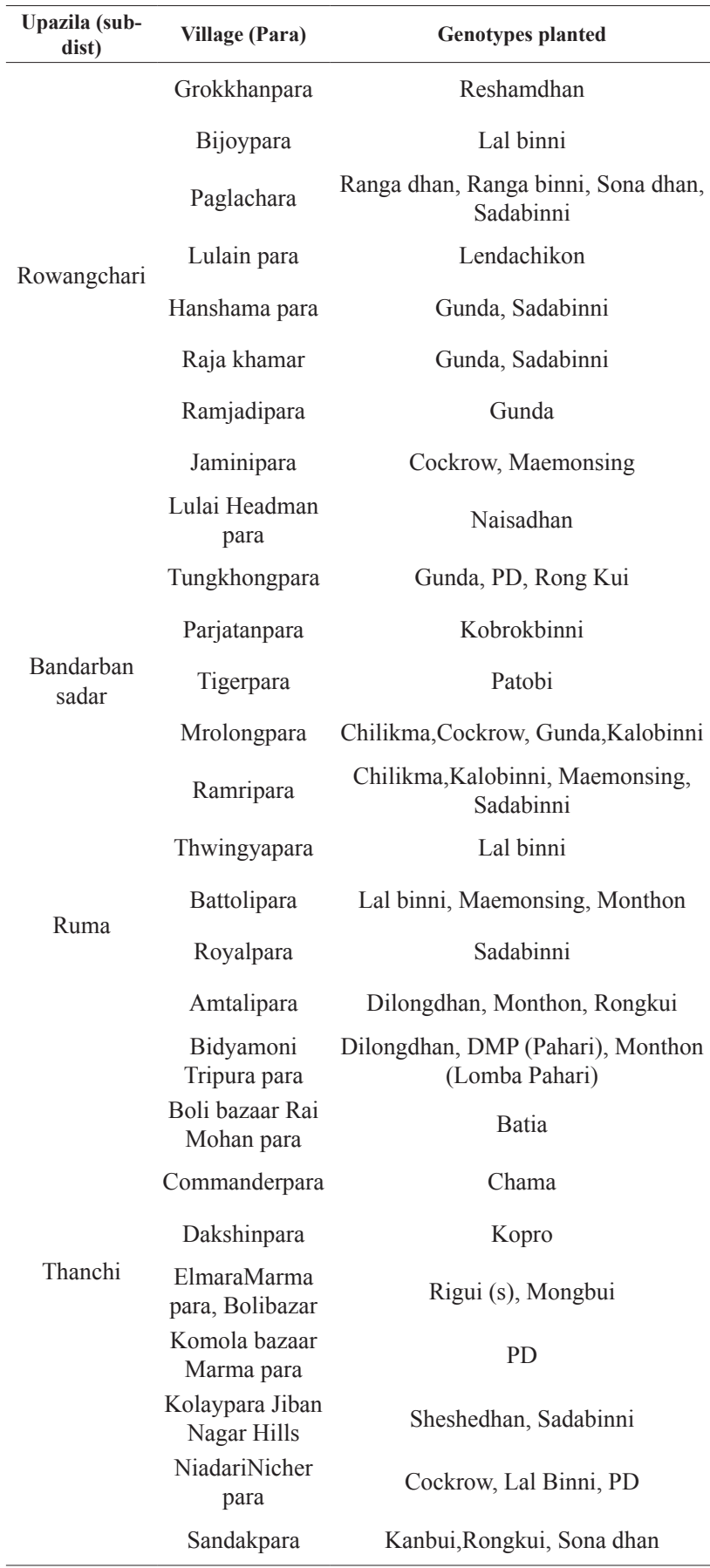

Scarcely occurring landraces like Batia, Chama, Chilikma, Dilon, DMP, Kanbui, Kopro, Mongpui, Rigui, Rongkui and Sheshe were planted in the mountains mostly in Thanchi. In Bandarban district, paddy is not traded in the market and rice is grown primarily for meeting household food requirements. It might be reasonably assumed that apart from ecological considerations, farmers' taste could be an important factor in selecting rice genotypes for cultivation in the study sites.
Table 2. Provenance of upland rice varieties planted in jhum in four upazila of Bandarban district

\begin{tabular}{|c|c|c|}
\hline $\begin{array}{l}\text { Variety/ } \\
\text { landrace }\end{array}$ & Provenance & $\begin{array}{c}\text { Farmers } \\
\text { involved } \\
\text { (No) }\end{array}$ \\
\hline Batia & Boli bazaar Rai Mohan para, Thanchi & 1 \\
\hline Chama & Commanderpara, Thanchi & 2 \\
\hline Chilikma & Mrolongpara, Ramripara, Bandarban sadar & 3 \\
\hline Cockrow & $\begin{array}{c}\text { Hanshamapara, Rajakhamar, Ramjadipara } \\
\text { (Rowangchari); Tungkhonpara, Mrolongpara } \\
\text { (Bandarban sadar) }\end{array}$ & 5 \\
\hline Dilon & Amtalipara, Bidyamoni Tripura para, Thanch & 2 \\
\hline $\begin{array}{l}\mathrm{DMP}(\mathrm{Pa}- \\
\text { hari) }\end{array}$ & Bidyamoni Tripura para, Thanchi & 1 \\
\hline Gunda & $\begin{array}{c}\text { Hanshamapara, Rajakhamar, Ramjadipara } \\
\text { (Rowangchari); Tungkhonpara, Mrolongpara } \\
\text { (Bandarban sadar) }\end{array}$ & 8 \\
\hline Kalobinni & Mrolongara, Ramripara (Bandarban sadar) & 5 \\
\hline Kanbui & Sandakpara, Thanchi & 2 \\
\hline $\begin{array}{l}\text { Kobrokbin- } \\
\text { ni }\end{array}$ & Parjatanpara, Bandarban & 1 \\
\hline Kopro & Dakshinpara (Thanchi) & 1 \\
\hline Lal binni & $\begin{array}{l}\text { Bijoypara (Rowangchari); Thwingyapara(Ban- } \\
\text { darban); Bottolipara(Ruma) }\end{array}$ & 5 \\
\hline $\begin{array}{l}\text { Lendachi- } \\
\text { kon }\end{array}$ & Lulain para, Rowangchari & 1 \\
\hline $\begin{array}{l}\text { Maemons- } \\
\text { ing }\end{array}$ & $\begin{array}{l}\text { Jaminipara (Rowaqngchari); Ramripara (Ban- } \\
\text { darban sadar); Bottolipara(Ruma) }\end{array}$ & 7 \\
\hline Mongbui & ElmaraMarma para, Bolibazar (Thanchi) & 2 \\
\hline Monthon & $\begin{array}{c}\text { Battolipara (Ruma), Amtolipara and Bidyamo- } \\
\text { ni Tripura para (Thanchi) }\end{array}$ & 6 \\
\hline $\begin{array}{l}\text { Monthon } \\
\text { (Lomba } \\
\text { Pahari) }\end{array}$ & Bidyamoni Tripura para (Thanchi) & 1 \\
\hline Naisadhan & Lulai Headman para (Bandarban sadar) & 1 \\
\hline Patobi & Tigerpara (Bandarban sadar) & 1 \\
\hline PD & $\begin{array}{c}\text { Tungkhongpara (Bandarban sadar), Komola } \\
\text { bazaar Marma para, Niadari Nich para (Than- } \\
\text { chi) }\end{array}$ & 5 \\
\hline $\begin{array}{c}\text { Ranga } \\
\text { binni }\end{array}$ & Paglachara (Rowangchari) & 2 \\
\hline Ranga dhan & Paglachara (Rowangchari) & 1 \\
\hline $\begin{array}{l}\text { Resham- } \\
\text { dhan }\end{array}$ & Gorokkhonpara (Rowangchari) & 1 \\
\hline $\begin{array}{l}\text { Rigui } \\
\text { (scented) }\end{array}$ & Elmara Marma para, Bolibazar (Thanchi) & 2 \\
\hline Rong Kui & Amtalipara, Sandakparaq (Thanchi) & 4 \\
\hline Sadabinni & $\begin{array}{c}\text { Paglachara, Hanshamapara, Raja Khamar } \\
\text { (Rowangchari); Ramripara (Bandarban sadar); } \\
\text { Royalpara(Ruma); Kolaypara Jiban Nagar } \\
\text { Hills (Thanchi) }\end{array}$ & 7 \\
\hline Sheshe & Kolaypara Jiban Nagar Hills, Thanchi & 1 \\
\hline Sona dhan & $\begin{array}{l}\text { Paglachara, Rowangchari; Sandakpara, Than- } \\
\text { chi }\end{array}$ & 3 \\
\hline
\end{tabular}

Crops in shifting cultivation are grown in sloping uplands without land tillage and depending on natural rainfall. Onset and termination of rainy season determine the length of crop growing season. Seeds of upland rice are 
dibbled on dry land surface without tillage and the stand establishment relies heavily on rainfall. Rainfall records of Bandarban (Figure 1) suggest that rainfall received in April and May 2019 was favorable for a good stand establishment of rice and other component crops in the hills. Rainfall peaked in July-August when upland rice was in reproductive and grain-filling stages. It is reasonable to assume that rice experienced a good rainfall sufficient for supporting its growth. Our observations are in agreement with Saito et al. ${ }^{[31]}$ who observed a close association between growing season rainfall and upland rice yield in Laos. Using 40 years' rainfall data Akinbile et al. ${ }^{[32]}$ demonstrated that rice yield was positively related with rainfall in Nigeria. In a classification and regression tree analysis of a dataset, Bruelle et al. ${ }^{[33]}$ showed rice yield was more affected by agro-environmental factors than management factors in Madagascar.

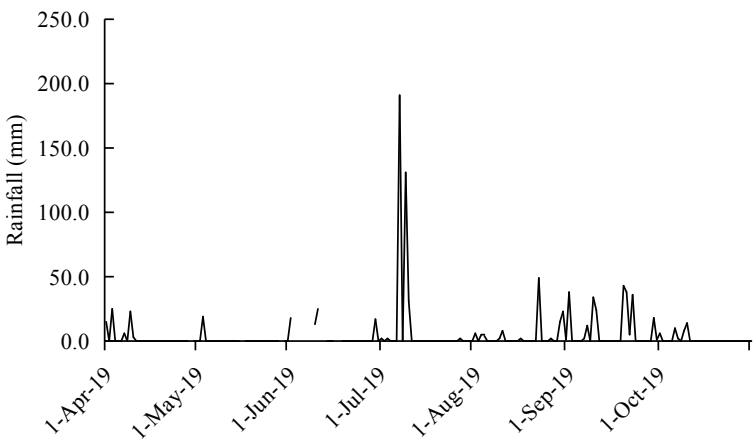

Figure 1. Rainfall pattern during experimental period, Bandarban, Bangladesh

Out of 28 landraces, each of 11 landraces had a single plot sample, and thus single plot sample yield data were used for these landraces. In other cases, the number of sample plots was unequal ranging from 2 to 8 . Rice grain yields differed remarkably across landraces. Intra-genotypic difference in grain yield was also enormous (Table 3). Rice grain yield ranged between $1.421 \mathrm{t} \mathrm{ha}^{-1}$ and 3.442 $\mathrm{t} \mathrm{ha} \mathrm{a}^{-1}$ showing a variation of over $142 \%$. The highest yield was recorded for a long-grain, aromatic, glutinous rice genotype Patobi. A bold grain, non-aromatic glutinous cultivar Dilon produced the lowest grain yield (Figure 2). Fairly high and stable yield was obtained for genotypes Gunda (3.058 tha $\left.{ }^{-1}\right)$, Maemongsing $\left(3.442 \mathrm{t} \mathrm{ha}^{-1}\right)$ and PD $\left(3.106 \mathrm{tha}^{-1}\right)$. In view of relatively higher price and greater demand, yield of Sadabinni (2.880 tha $\mathrm{ha}^{-1}$ ) looks also reasonably good. The highest yield was obtained for the genotype Patobi; but because of sample size direct comparison of Patobi and other scarcely occurring landraces with those of frequently occurring landraces could not be made. Our results are in agreement with Zewdu et al. ${ }^{[34]}$ who observed a wide variability in grain yield of upland rice which they attributed to differences in the test locations in Ethiopia and genotypic variations. Earlier, Van Keer et al. ${ }^{[35]}$ also reported extensive variability in productivity of tropical japonica type glutinous upland rice varieties in an extensive research area in northern Thailand. Haryanto et al. ${ }^{[36]}$ also reported wide variability in upland genotypes with significant genotype $\mathrm{x}$ environment interaction.

Table 3. Variations in grain yield of upland rice genotypes in Bandarban, Bangladesh

\begin{tabular}{|c|c|c|c|}
\hline \multirow{2}{*}{ Variety/Landrace } & \multirow{2}{*}{$\begin{array}{l}\text { Grain yield } \\
\text { range }\left(t \text { ha }^{-1}\right)\end{array}$} & \multicolumn{2}{|c|}{ Relative performance agains } \\
\hline & & BRRI dhan83 & Gunda \\
\hline Batia & - & 0.8152 & 0.6825 \\
\hline Chama & $1.804-2.066$ & 0.7047 & 0.5899 \\
\hline Chilikma & $1.154-2.760$ & 0.5805 & 0.4859 \\
\hline Cockrow & $1.701-2.812$ & 0.8875 & 0.7430 \\
\hline Dilon & $1.340-1.502$ & 0.5551 & 0.4647 \\
\hline DMP (Pahari) & - & 0.8156 & 0.6828 \\
\hline Gunda & $2.190-4.012$ & 1.1945 & 1.0000 \\
\hline Kalobinni & $0.752-2.047$ & 0.6203 & 0.5193 \\
\hline Kanbui & $1.765-2.120$ & 0.7605 & 0.6367 \\
\hline Kobrokbinni & - & 1.2363 & 1.0350 \\
\hline Kopro & - & 0.8703 & 0.7286 \\
\hline Lal binni & $1.340-3.096$ & 0.8563 & 0.7168 \\
\hline Lendachikon & - & 0.8047 & 0.6736 \\
\hline Maemonsing & $2.056-4.126$ & 1.3324 & 1.1154 \\
\hline Mongbui & $1.744-2.910$ & 0.8141 & 0.6815 \\
\hline Monthon & $1.654-3.763$ & 1.2602 & 1.0549 \\
\hline $\begin{array}{l}\text { Monthon (Lomba Paha- } \\
\text { ri) }\end{array}$ & - & 1.0000 & 0.8371 \\
\hline Naisadhan & - & 0.6039 & 0.5056 \\
\hline Patobi & - & 1.3445 & 1.1256 \\
\hline PD & $2.098-3.888$ & 1.2133 & 1.0157 \\
\hline Ranga binni & & 0.8387 & 0.7021 \\
\hline Ranga dhan & - & 0.7578 & 0.6344 \\
\hline Reshamdhan & - & 0.8156 & 0.6828 \\
\hline Rigui (scented) & $1.405-1.906$ & 0.6465 & 0.5412 \\
\hline Rong Kui & $1.614-3.487$ & 0.9563 & 0.8005 \\
\hline Sadabinni & $1.554-3.561$ & 1.1250 & 0.9418 \\
\hline Sheshe & - & 1.0000 & 0.8371 \\
\hline Sona dhan & $1.326-2.066$ & 0.6168 & 0.5164 \\
\hline
\end{tabular}

- Data not available 


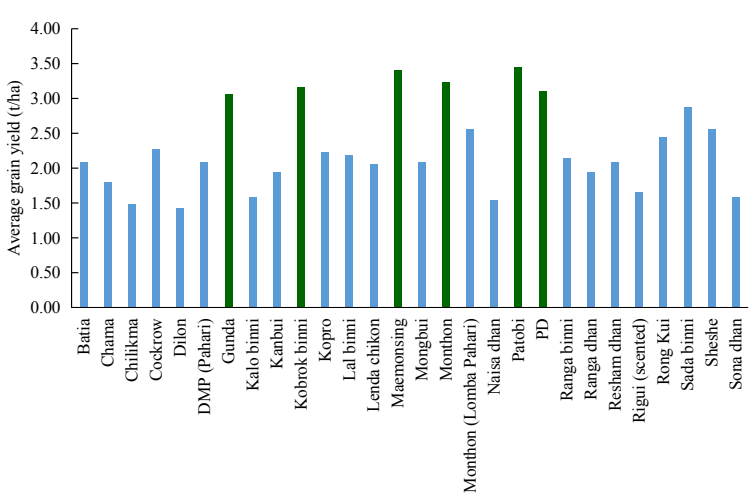

Figure 2. Average grain yield of upland rice genotypes in Bandarban, Bangladesh

Relative performances of local landraces in terms of grain yields were better or similar for Kobrokbinni, Maemonsing, Monthon, Patobi, and PD compared to BRRI dhan 83 and Gunda (Table 3). These clearly indicate that some of the landraces are having potentiality of giving relatively higher grain yields at least in certain specific locations. Yield enhancement of these potential landraces could be tried providing improved agronomic management conditions. These may also be used as parent materials for developing drought tolerant high yielding varieties for adaptation in hilly areas.

All the upland rice landraces sampled in the study were grown in shifting cultivation. Frequency of occurrence of the landraces also differed a great deal across locations, except the genotype Sadabinni. However, all the landraces did not occur evenly throughout the study locations. Hence, analysis of spatial differences in rice grain yields or variety $x$ location effect on yield variation was not attempted.

\section{Conclusions}

In the Chattogram Hill Tracts (CHT) in general, and Bandarban in particular, shifting cultivation has been the dominant upland rice ecosystems primarily due to land topography and socio-economic characteristics of the ethnic communities. Production of upland rice in shifting cultivation has been a key of food security for the resource-poor farmers in Bandarban. Most hill farmers prefer glutinous upland rice (like Binni, Patobi, Rigui etc.), but moderate yielding landraces are now gaining ground due to yield stability across locations and seasons. Farmers in Bandarban sadar, in the high range hills in southern Rowangchari and in Ruma prefer landraces Gunda, Maemonsingh and Monthon because of drought tolerance. In contrast, provenance of landraces like Cham, Chilikma, Kopro, Lenda chikon, Patobi, Resham dhan, Rigui and Sona dhan are in specific locations and probably have no wider adaptability or farmers' acceptability. For a long time, these location specific landraces endured harsh environment and adapted to local agro-climatic conditions with names that farmers selected and maintained to meet their social, economic, cultural and ecological needs ${ }^{[37]}$. Landraces are not considered in the public seed production and distribution system. In this study, the landraces showing potentiality of high yields across locations (for example, Gunda, Monthon) may be released as varieties for wider dissemination in the hilly areas.

\section{Acknowledgement}

The work was partially funded by a grant from the Ministry of Science and Technology, Government of Bangladesh.

\section{References}

[1] Xu JC. The political, social, and ecological transformation of a landscape - the case of rubber in Xishuangbanna, China. Mountain Research and Development, 2006, 26: 254-262.

[2] Fox J, Fujita Y, Ngidang D, Peluso N, Potter L, Sakuntaladewi N, Sturgeon J, Thomas D. Policies, Political-Economy, and Swidden in Southeast Asia. Human Ecology, 2009, 37: 305-322.

[3] Nath TK, Inoue M, Chakma S. Shifting Cultivation (jhum) in the Chittagong Hill Tracts, Bangladesh: Examining its Sustainability, Rural Livelihood and Policy Implications. Int. J. Agric. Sust., 2005, 3(2): 130-142.

[4] Hossain MI, Riyadh ZA, Ferdausi J, Rahman MA, Saha SR. Crop agriculture of Chittagong Hill Tracts: Reviewing its management, performance, vulnerability and development model. Intl. J. Agric. \& Env. Res., 2020, 6(5): 707-727.

[5] Forestal Forestry and Engineering International Limited (Forestal). Chittagong Hill Tracts: soil and land use survey (1964-1966), vol 2, 1996, Vancouver, Canada.

[6] Quais MK, Rashid MM, Shahidullah SM, Nasim M. Crops and Cropping Sequences in Chittagong Hill Tracts. Bangladesh Rice J, 2017, 21 (2) : 173-184.

[7] Huang X, Kurata N, Wei X, Wang ZX, Wang A, Zhao Q, Zhao Y, Liu K, Li W, Guo Y et al. A map of rice genome variation reveals the origin of cultivated rice. Nature, 2012, 490: 497-501.

[8] Nakagahara M. The differentiation, classification and center of genetic diversity of cultivated rice (Oryza sativa L.) by isozyme analysis. Trop. Agric. Res. Sci., 1978, 11: 77-82.

[9] Das B, Sengupta S, Parida SK, Roy B, Ghosh M, Prasad M, Ghose TK. Genetic diversity and popu- 
lation structure of rice landraces from Eastern and North Eastern States of India. BMC Genetics, 2013, 14.71 .

[10] Warner K. Shifting cultivators: Local technical knowledge and natural resource management in the humid tropics. Food and Agriculture Organization of The United Nations, Rome. 1991.

[11] Li P, Feng Z, Jiang L, Liao C, Zhang J. A Review of Swidden Agriculture in Southeast Asia. Remote Sens., 2014, 6: 1654-1683.

DOI: $10.3390 /$ rs 6021654

[12] Siahaya M, Hutauruk TR, Aponno HSES, Hatulesila JW, Mardhanie AB. Traditional ecological knowledge on shifting cultivation and forest management in East Borneo, Indonesia. Intl. J. Biodiversity Sci. Ecosystem Services \& Management, 2016, 12(12):14-23.

DOI: $10.1080 / 21513732.2016 .1169559$.

[13] Rasul G, Thapa GB. Shifting cultivation in the mountains of South and Southeast Asia: Regional patterns and factors influencing the changes. Land Degradation and Development, 2003, 14:495-508. doi: 10.1002/ldr.570.

[14] Nahar A, Akbar MA, Biswas JC, Gafur A, Uddin MF, Rasid S, Mollah MAM, Marma MS, Marma TM, Marma SSM, Islam MK, Neogi MG, Hamid A. Household Demography and Food Security of Jhum Farmers in Bandarban District, Bangladesh. Journal of Applied Agricultural Economics and Policy Analysis, 2020, 3(1): 8-14.

DOI:10.12691/jaaepa-3-1-2.

[15] Saito K, Asai H, Zhao D, Laborte AG, Grenier C. Progress in varietal improvement for increasing upland rice productivity in the tropics. Plant Production Sci, 2018, 21(3): 145-158. DOI: $10.1080 / 1343943 X .2018 .1459751$.

[16] Ghimire R, Wen-chi H, Shrestha RB. Factors Affecting Adoption of Improved Rice Varieties among Rural Farm Households in Central Nepal. Rice Science, 2015, 22(1): 35-43.

[17] Choudhury B, Khan ML, Dayanandan S. Genetic structure and diversity of indigenous rice (Oryza sativa) varieties in the Eastern Himalayan region of Northeast India. SpringerPlus, 2013, 2:228.

[18] Atlin GN, Lafitte HR, Tao D, Laza M, Amante M, Courtois B. Developing rice cultivars for high-fertility upland systems in the Asian tropics. Field Crops Research, 2006, 97: 43-52.

[19] Van Andel T, Veltman MA, Bertin A, Maat H, Polime T, Hille Ris Lambers D, Tjoe Awie J, De Boer H, Manzanilla V. Hidden Rice Diversity in the Guianas. Front. Plant Sci., 2019, 10:1161.
DOI: 10.3389/fpls.2019.01161.

[20] Mahmud S, Alam MR, Amin M, Hassan MM. Performances of improved and traditional rice based jhum cultivation in a hill district of Bangladesh. J Bangladesh Agril Univ, 2018, 16(2): 193-197.

DOI: 10.3329/jbau.v16i2.37960.

[21] Barah BC, Pandey S. Rainfed Rice Production Systems in Eastern India: An On-Farm Diagnosis and Policy Alternatives. Ind. Jn. of Agri. Econ., 2005, 60: 110-136.

[22] Ran Y, Chen H, Ruan D, Liu H, Wang S, Tang X, et al. Identification of factors affecting rice yield gap in southwest China: An experimental study. PLoS ONE, 2018, 13(11): e0206479. https://doi.org/10.1371/ journal.pone.0206479.

[23] Sadimantara GR, Kadidaa B, Suaib, Safuan LO, Muhidin. Growth performance and yield stability of selected local upland rice genotypes in Buton Utara of Southeast Sulawesi. IOP Conf. Series: Earth and Environmental Science, 2018, 122: 012094. DOI :10.1088/1755-1315/122/1/012094.

[24] Roy S, Marndi BC, Mawkhlieng A, Banerjee RM, Yadav AK, Misra AK, Bansal, KC. Genetic diversity and structure in hill rice (Oryza sativa L.) landraces from the North Eastern Himalayas of India. BMC Genetics, 2016, 17:107.

DOI: 10.1186/s12863-016-0414-1.

[25] Siddique MA, Islam MZ, Khalequzzaman M and Ahmed MS, MS. Genetic diversity in rice (Oryza sativa L.) landraces of hilly areas in Bangladesh. Bangladesh J. Pl. Breed. Genet., 2011, 24(2): 25-30.

[26] Mantel S, Mohiuddin M, Alam MK, Olarieta JR, Alam M, Khan FMA. Improving the jhum system in Bangladesh. LEISA Mag., 2006, 22(4):20-21.

[27] Gafur A, Jensen JR, Borggaard OK, Petersen L. Runoff and losses of soil and nutrients from small watersheds under shifting cultivation (Jhum) in the Chittagong Hill Tracts of Bangladesh. Journal of Hydrology, 2003, 279: 293-309.

[28] Tian W, Li L, Liu F, Zhang Z, Yu G, Shen Q, Shen B. Assessment of the maturity and biological parameters of compost produced from dairy manure and rice chaff by excitation-emission matrix fluorescence spectroscopy. Bioresour Technol, 2012, 110:330-7.

[29] Bangladesh Rice Research Institute (BRRI). Annual Research Review Workshop, 2019-2020. XVI: Adaptive Research Division, BRRI, Gazipur, 53p, 2021.

[30] Vanlalsanga S, Singh P, Singh YT. Rice of Northeast India harbor rich genetic diversity as measured by SSR markers and $\mathrm{Zn} / \mathrm{Fe}$ content. BMC Genetics, 2019, 20:79 doi.org/10.1186/s12863-019-0780-6.

[31] Saito K, Linquist B, Keobualapha B, Phanthaboon K, 
Shiraiwa T, Horie T. Cropping intensity and rainfall effects on upland rice yields in northern Laos. Plant and Soil, 2006, 284: 175-185.

[32] Akinbile CO, Ogunmola OO, Abolude AT, Akande SO. Trends and spatial analysis of temperature and rainfall patterns on rice yields in Nigeria. Atmospheric Sci. Letters, 2019, 21(3): e944. doi.org/10.1002/ asl.944.

[33] Bruelle G, Naudin K, Scopel E, Domas R, Rabeharison L, Tittonell P. 2014. Short- to mid-erm impact of conservation agriculture on yield variability of upland rice: Evidence from farmer's fields in Madagascar. Experimental Agriculture, 1996, 51:66-84. doi. org/10.1017/S0014479714000155.

[34] Zewdu Z, Abebe T, Mitiku T, Worede F, Dessie A, Berie A, Atnaf M. Performance evaluation and yield stability of upland rice (Oryzasativa L.) varieties in Ethiopia, Cogent Food \& Agriculture, 2020, 6:1, 1842679.

DOI: $10.1080 / 23311932.2020 .1842679$.

[35] Van Keer K, Trebuil G, Courtois B, Vejpas C. Onfarm characterization of upland rice varieties in North Thailand. International Rice Research Notes, 1998, 23 (3): 21-22.

[36] Haryanto TAD, Suwarto S, Yoshida T. Yield Stability of Aromatic Upland Rice with High Yielding Ability in Indonesia. Plant Prod. Sci., 2008, 11(1): 96-103.

[37] Teshome A, Baum BR, Fahrig L, Torrance JK, Arnason TJ, Lambert JD. Sorghum (Sorghum bicolor L.) Moench) landrace variation and classification in North Shewa and South Welo, Ethiopia. Euphytica, 1997, 97: 255-263. 